\begin{tabular}{llll} 
ZAPISKI HISTORYCZNE & - TOM LXXXIV \\
Zeszyt 4 & - ROK 2019 \\
\hline
\end{tabular}

Articles

http://dx.doi.org/10.15762/ZH.2019.38

TOMASZ AMBROZIAK

(Ural Federal University, Yekaterinburg)

\title{
IVAN IVANOVICH LAPPo's VIEWS \\ on the Circumstances of Establishing the Union of Lublin in the Context of Pre-Revolutionary Russian Historiography
}

Key words: Polish-Lithuanian Commonwealth, Grand Duchy of Lithuania, Union of Lublin, Ivan Ivanonich Lappo, Russian historiography, history of historiography

In contemporary science, an extremely important role is played by research on the history of historiography. Its significance results not only from our purely cognitive curiosity, but also from its practical advantages. Knowledge of the past achievements of historiography, methodology of research or scholars' views is, after all, extremely important for the formulation and undertaking of new research topics. Therefore, we should be glad that the Polish-Lithuanian unions and, more generally, the history of the Grand Duchy of Lithuania, are also interesting from the point of view of the history of historiography ${ }^{1}$.

\footnotetext{
${ }^{1}$ Cf., for example: Валеры Шэйфер, Дзяржаўныя уніі Вялікага Княства Літоускага і Каралеўства Польскага у у аиэнцы расейскай гістарыяграфіі 19 - першых дзесяиігоддзяу 20 cm., Гістарычны Альманах, T. 5: 2000 [Valery Sheyfer, Dzyarzhaŭnyya unii Vyalikaga Knyastva Litoŭskaga i Karaleŭstva Polskaga ŭ atsentsy raseyskay gistaryyagrafii 19 - pershykh dzesyatsigoddzyaŭ 20 st., Gistarychny Almanakh, vol. 5: 2000], pp. 123-134; Mečislovas JUčAs, Unia polsko-litewska, tł. Andrzej Firewicz, Toruń 2004, pp. 9-80; Grzegorz BŁAszczyк, Dzieje stosunków polsko-litewskich, t. 2: Od Krewa do Lublina, cz. 1, Poznań 2007, pp. 15-26; Алексей M. Столяров, История Великого княжества Литовского в отечественной историографии XIX - начала XX века (PhD diss. [Kazan State University]), Казань 2008 [Aleksey M. SToLYAROv, Istoriya Velikogo knyazhestva Litovskogo v otechestvennoy istoriografii XIX - nachala XX veka (PhD diss. [Kazan State University]), Kazan 2008]; Dorota Michaluk, Unia lubelska w polskiej historiografii XIX i XX wieku, [in:] Unia lubelska z 1569 roku. Z tradycji unifikacyjnych I Rzeczypospolitej, ed. Tomasz Kempa, Krzysztof Mikulski, Toruń 2011, pp. 151-184; Jelena Rusina, Unia lubelska w historiografii ukraińskiej, [in:] Unia lubelska. Idea i jej kontynuacja. Materiały z międzynarodowej konferencji naukowej, która odbyła się w dniach 19-20 listopada 2009 roku w Wilnie w Muzeum Sztuki Użytkowej, ed. Liudas GlemžA, Ramunè ŠMigelsKytė-Stukiené, Vilnius 2011, pp. 389-394; Andrzej B. Zakrzewski, Wielkie Księstwo Litewskie (XVI-XVIII w.): Prawo - ustrój - społeczeństwo, Warszawa 2013, pp. 9-31; Anna CzernieCKA-Haвerko, Unie polsko-litewskie w historiografii polskiej, Toruń 2013.
} 
This article presents the views of Ivan Ivanovich Lappo ${ }^{2}$, one of the leading researchers in the history of the Grand Duchy of Lithuania, on the circumstances of establishing the Union of Lublin in the context of the views of Russian pre-revolutionary historiography. The subject of the research will be the concept of the Union of Lublin presented by I. Lappo in his work: Beликое княжество Литовское за время от заключения Люблинской Унии до смерти Стефана Батория [Velikoye knyazhestvo Litovskoye za vremya ot zaklyucheniya Lyublinskoy Unii do smerti Stefana Batoriya] ${ }^{3}$.

It would be appropriate to begin our deliberations with a cursory review of the work of Russian researchers on this issue. It should be noted that in Russian pre-revolutionary historiography, the Grand Duchy of Lithuania was initially given little attention as a separate subject of research. It was considered primarily from the point of view of the role it played in the history of Russia ${ }^{4}$. In the works of Mikhail Mikhailovich Shcherbatov ${ }^{5}$ or Nikolay Mikhailovich Karamzin $^{6}$, supporters of the concept of the existence of a single centre of Russian statehood, which in general was a continuation of the model of perceiving

${ }^{2}$ On the biography of I. Lappo see for example: Aivas RAgAuskAs, Istorikas I. Lappo ir Lietuva, [in:] Lietuvos istorijos metraštis, Vilnius 1994, pр. 81-91; Владимир П. Мякишев, И. И. Лаппо - ученый с живым чувством исторической действительности, Вестник ВГУ. Серия Гуманитарные науки, 2004, no. 1 [Vladimir P. MYAкishev, I. I. Lappo - uchenyy s zhivym chuvstvom istoricheskoy deystvitelnosti, Vestnik VGU. Seriya Gumanitarnyye nauki, 2004, no. 1], pp. 162-176, http://kfinkelshteyn.narod.ru/Tzarskoye_Selo/Uch_zav/Nik_Gimn/ NG_prep_Lappo_Miakishev.htm [accessed July 1, 2019]; Людмила Дубьева, “Отдаюсь науке совсем...”. И. И. Лаппо - профессор русской истории Тартуского (Юрьевского) университета в 1905-1918 г2., [in:] Балтийский архив. Русская культура в Прибалтике, Т. 9, ред. Павел Лавринец, Вильнюс 2005 [Lyudmila DubyevA, “Otdayus nauke sovsem...”. I. I. Lappo professor russkoy istorii Tartuskogo (Yuryevskogo) universiteta v 1905-1918 gg., [in:] Baltiyskiy arkhiv. Russkaya kultura v Pribaltike, vol. 9, ed. Pavel LAvrinets, Vilnyus 2005], pp. 374-391.

${ }^{3}$ Иван И. Лаппо, Великое княжество Литовское за время от заключения Люблинской Унии до смерти Стебана Батория, Санкт-Петербург 1901 [Ivan I. LAppo, Velikoye knyazhestvo Litovskoye za vremya ot zaklyucheniya Lyublinskoy Unii do smerti Stefana Batoriya, Sankt-Peterburg 1901].

${ }^{4}$ Андрей Ю. Дворниченко, Историография Великого княжества Литовского и “Очерк истории Литовско-Русского государства” М. К. Любавского, Труды Исторического факультета Санкт-Петербургского университета, no.: 12: 2013 [Andrey Y. Dvornichenko, Istoriografiya Velikogo knyazhestva Litovskogo i "Ocherk istorii Litovsko-Russkogo gosudarstva" M. K. Lyubavskogo, Trudy Istoricheskogo fakulteta Sankt-Peterburgskogo universiteta, no. 12: 2013], p. 98.

${ }^{5}$ Михаил М. Щербатов, История российская от древнейших времен, Санкт-Петербург, т. 1-7, 1770-1791 [Mikhail M. SHсHERвATov, Istoriya rossiyskaya ot drevneyshikh vremen vol. 1-7, Sankt-Peterburg 1770-1791].

${ }^{6}$ Николай М. Карамзин, История государства Российского, т. 1-12, Санкт-Петербург 1818-1829 [Nikolay M. KARAmzIN, Istoriya gosudarstva Rossiyskogo, vol. 1-12, Sankt-Peterburg 1818-1829]. 
history developed in Moscow as early as in the $15^{\text {th }}-16^{\text {th }}$ centuries $^{7}$, it was considered an invader that conquered the fragmented Ruthenian lands in the west.

A new concept for the history of the Grand Duchy of Lithuania was developed in Russian historiography in the 1830s by Nikolay Gerasimovich Ustryalov. He presented it in the work entitled Русская история [Russkaya istoriya] ${ }^{8}$, written on the basis of his lectures, as well as in a small-sized but significant work Исследование вопроса, какое место в русской истории должно занимать Великое княжество Литовское? [Issledovaniye voprosa, kakoye mesto $v$ russkoy istorii dolzhno zanimat Velikoye knyazhestvo Litovskoye ${ }^{9}$. The latter played an important role in transforming the Grand Duchy of Lithuania into a separate subject of study. The Grand Duchy, according to this researcher, was not only a purely Ruthenian state, but also a centre of unified Ruthenian lands after a period of fragmentation, fully equivalent to Moscow.

Ustryalov's assessment of the union with the Kingdom of Poland was extremely negative. According to him, the union became a reason why the Grand Duchy of Lithuania lost its significance in the history of Russia and a source of captivity ${ }^{10}$. The Union of Lublin and the death of the last Jagiellonian monarch were the moments when "западная Русь сделалась добычей иезуитов, старавшихся истребить в ней все Русское, и к концу XVII века она действительно утратила многие черты своей национальности: Русские законы уступили место польским; язык был искажен; нравы и обычаи изменились; уния поколебала и веру православную" ["Western Ruthenia became the prey of the Jesuits, who tried to destroy everything that was Russian there, and at the end of the $17^{\text {th }}$ century it actually lost many of its national characteristics: Russian laws gave way to Polish laws; the language became distorted; moral norms and customs changed; the Union also shook the Orthodox faith"] ${ }^{11}$. The Union thus opened the way for the loss of independence for the Grand Duchy, which not only lost its legitimacy in the rivalry for the reunification of the Ruthenian lands, but also needed to be rescued by the true rulers of Ruthenia, i.e. the monarchs of Moscow.

${ }^{7}$ Павел Н. Милюков, Главные течения русской исторической мысли, Санкт-Петербург 1913 [Pavel N. MiLyuкov, Glavnyye techeniya russkoy istoricheskoy mysli, Sankt-Peterburg 1913], pp. 167-172.

${ }^{8}$ Николай Г. Устрялов, Русская история, Ч. 1-5, Санкт-Петербург 1837-1841 [Nikolay G. Ustryalov, Russkaya istoriya, vol. 1-5, Sankt-Peterburg 1837-1841].

${ }^{9} \mathrm{Idem}$, Исследование вопроса, какое место в русской истории должно занимать Ветикое княжество Литовское, Санкт-Петербург 1839 [Issledovaniye voprosa, kakoye mesto $v$ russkoy istorii dolzhno zanimat Velikoye knyazhestvo Litovskoye, Sankt-Peterburg 1839].

${ }^{10}$ Ibid., p. 37.

${ }^{11}$ Ibid., pp. 19-20. 
The concept of N. Ustryalov, after it had been approved by the Minister of Education Sergey Semionovich Uvarov became an official state concept, and his Русская история became the basic school textbook on Russian history. What is more, the dualistic concept of the development of Russia became the basis for other works, such as Konstantin Nikolayevich Bestuzhev-Ryumin's Русская история [Russkaya istoriya $]^{12}$.

In the area of narrower, more specific research, N. Ustryalov's ideas were applied by his student, a professor at the Imperial Novorossiya University, Mikhail Pavlovich Smirnov. In his works ${ }^{13}$ he claimed that the Grand Duchy of Lithuania, which in fact was a Ruthenian state, became completely subjected to Poland as a result of the Union of Lublin, to which it was forced due to the difficult external and internal situation.

Sergey Mikhailovich Solovyov ${ }^{14}$, despite some significant differences in relation to the concept of N. Ustryalov, also presented a very negative assessment of the Union of Lublin in his История России с древнейихх времен [Istoriya Rossii s drevneyshikh vremen]. The dependence on Poland, imposed by the Union, did not satisfy the Lithuanian nobility, who kept fighting for their own position. According to Solovyov, the situation of Lithuania and Ruthenia under the Jagiellonian rule, was not yet dramatic. However, it deteriorated rapidly after the conclusion of the Union of Lublin, which gave the Poles and the Catholic clergy a complete freedom to act (including the liquidation of the Orthodox Church). This provoked opposition from Lithuania and Ruthenia and led to an uprising in Ukraine and its merger with Russia, followed by the fall of the Polish-Lithuanian Commonwealth ${ }^{15}$.

Mikhail Osipovich Koyalovich, a professor of the St. Petersburg Theological Academy, a well-known current affairs commentator and a representative

${ }^{12}$ Константин Н. Бестужев-Рюмин, Русская история, т. 1-2, Санкт-Петербург 1872-1885 [Konstantin N. Bestuzhev-Ryumin, Russkaya istoriya, vol. 1-2, Sankt-Peterburg 1872-1885].

${ }^{13}$ Михаил П. Смирнов, Ягелло-Яков-Владислав и первое соединение Литвы с Польшей, Записки Императорского Новороссийского университета, 1868, T. 2 [Mikhail P. Smirnov, Yagello-Yakov-Vladislav i pervoye soyedineniye Litvy s Polshey, Zapiski Imperatorskogo Novorossiyskogo universiteta, 1868, vol. 2], pp. 1-259; idem, Спор между Литвой и Польшей о правах на Волынь и Подолию, [in:] Торнественный акт Ришельевского тищея по случаю окончания 1862-63 академического года, Одесса 1863 [Spor mezhdu Litvoy i Polshey o pravakh na Volyn i Podoliyu, [in:] Torzhestvennyy akt Rishelyevskogo litseya po sluchayu okonchaniya 1862-63 akademicheskogo goda, Odessa 1863], pp. 5-71.

${ }^{14}$ Сергей М. Соловьев, История России с древнейших времен, Кн. 1-6, Санкт-Петербург 1851-1879 [Sergey M. Solovyev, Istoriya Rossii s drevneyshikh vremen, vol. 1-6, Sankt-Peterburg 1851-1879].

${ }^{15}$ Katarzyna BŁAchowsкa, Wiele historii jednego państwa. Obraz dziejów Wielkiego Księstwa Litewskiego do 1569 roku w ujęciu historyków polskich, rosyjskich, ukraińskich, litewskich i białoruskich w XIX wieku, Warszawa 2009, pp. 189-210. 
of West-Russism ${ }^{16}$, was even more critical of the Union of Lublin and its consequences ${ }^{17}$. Continuing the ideas of N. Ustryalov, he viewed the Grand Duchy of Lithuania in his works ${ }^{18}$ as a Ruthenian state, which was harmed by Polish influences. He saw the entire history of Polish-Lithuanian relations as the history of Lithuanian and Ruthenian struggle against the Polish forceful incorporation of them into a single state and the suppression of natural differences between the two nations. Koyalovich was particularly negative about the Union of Lublin, which he called the 'last union' of Lithuania and Poland ${ }^{19}$. It is also worth noting that M. Koyalovich was a publisher of the journal of the Sejm of Lublin of $1569^{20}$.

The assessment of the Union of Lublin by Mitrofan Viktorovich Dovnar-Zapolskiy ${ }^{21}$ was not as acute, though still negative. In his opinion, the Union

${ }^{16}$ Cf. Аляксандр І. Цьвікевіч, Западно-руссизм. Нарысы з гісторы грамадскай мысьлі на Беларусі у XIX і пачатку XX в., Мінск 1993 [Alyaksandr I. Tsviкevich, Zapadno-russizm. Narysy z gistoryi gramadskay mysli na Belarusi u XIX i pachatku XX v., Minsk 1993]; Леонид Е. Горизонтов, Западнорусизм в мире идентичностей межславянского пограничья. Историографические наблюдения, [in:] Славянский мир. В поисках идентичности, Москва 2011 [Leonid E. GorizonTov, Zapadnorusizm v mire identichnostey mezhslavyanskogo pogranichia. Istoriograficheskiye nablyudeniya, [in:] Slavyanskiy mir. V poiskakh identichnosti, Moskva 2011], pp. 930-939.

${ }^{17}$ Cf. Валерий Н. Черепица, Михаил Осипович Коялович. История жизни и творчества, Гродно 1998 [Valeriy N. CherePITSA, Mikhail Osipovich Koyalovich. Istoriya zhizni i tvorchestva, Grodno 1998]; Анатолий А. Чернобаев, Коялович Михаил Осипович, [in:] Историки России. Биограбии, Москва 2001 [Anatoliy A. CHernoвAYev, Koyalovich Mikhail Osipovich, [in:] Istoriki Rossii. Biografii, Moskva 2001], pp. 223-228.

${ }^{18}$ Михаил О. Коялович, Люблинская уния, или последнее соединение литовского княжества с польским, Санкт-Петербург 1863 [Mikhail O. KoYalovich, Lyublinskaya uniya, ili posledneye soyedineniye litovskogo knyazhestva s polskim, Sankt-Peterburg 1863]; idem, Лекu,u nо истории Западной России, Москва 1864 [Lektsii po istorii Zapadnoy Rossii, Moskva 1864]; idem, Историческое исследование о Западной России, служащее предисловием к документам, объясняюшим историю западнорусского края и его отношения к России и к Польше, Санкт-Петербург 1865 [Istoricheskoye issledovaniye o Zapadnoy Rossii, sluzhashcheye predisloviyem $k$ dokumentam, obyasnyayushchim istoriyu zapadnorusskogo kraya $i$ ego otnosheniya $k$ Rossii i $k$ Polshe, Sankt-Peterburg 1865].

${ }^{19}$ М. О. Коялович, Люблинская уния, р. 22.

${ }^{20}$ Дневник Люблинского сейма 1569 года. Соединение Великого княжества Литовского с Королевством Польским, Санкт-Петербург 1869 [Dnevnik Lyublinskogo seyma 1569 goda. Soyedineniye Velikogo knyazhestva Litovskogo s Korolevstvom Polskim, Sankt-Peterburg 1869].

${ }^{21}$ Митрофан В. Довнар-Запольский, Польско-Литовская уния на сеймах до 15692. Исторический очерк, Москва 1897 [Mitrofan V. Dovnar-ZApolskiy, Polsko-Litovskaya uniya na seymakh do $1569 \mathrm{~g}$. Istoricheskiy ocherk, Moskva 1897]; idem, Государственное хозяйство Великого княжества Литовского при Ягелонах, Киев 1901 [Gosudarstvennoye khozyaystvo Velikogo knyazhestva Litovskogo pri Yagelonakh, Kiyev 1901]; idem, Сnорные вопросы в истории Литовско-Русского сейма, Журнал министерства народного просвещения, 1901, no. 10 [Spornyye voprosy $v$ istorii Litovsko-Russkogo seyma, Zhurnal ministerstva narodnogo prosveshcheniya, 1901, no. 10], pp. 454-498. 
led to religious intolerance and the rule of feudal nobility, and the period after 1569 became a time of economic and political degradation for the Grand Duchy.

Basically, Pavel Dmitriyevich Bryancev, the author of the general work devoted to the history of the Grand Duchy of Lithuania, remained in the existing tradition of describing the Union of Lublin ${ }^{22}$. At the same time, however, as Alexey Mikhailovich Stolyarov notes, P. Bryancev's unquestionable achievement was to notice that the development of relations within the Grand Duchy, especially as regards the position of the ruler and the political significance of the magnates, brought Lithuania closer to Poland, thus preparing the ground for the conclusion of the Union ${ }^{23}$.

Pre-revolutionary Russian historiography was not limited to great narratives, but also works on specific issues were created as part of it. It was in the Russian historiography of the late $19^{\text {th }}$ and early $20^{\text {th }}$ centuries that research on legal institutions and authorities in the Grand Duchy of Lithuania developed remarkably, including the works of Nikolay Alexeyevich Maksimieyko ${ }^{24}$ and Matvey Kuzmich Lyubavskiy ${ }^{25}$.

The latter, in his work devoted to the history of the Lithuanian Parliament until the Union of Lublin, which in his opinion was "de jure и de facto [...] главным носителем верховной власти государства” [“de jure and de facto, the main carrier of supreme state power" ${ }^{26}$, looked at the history of Lithuanian statehood from the point of view of the development of the Sejm. At the same time, it was the history of the reception of Polish model of the government that he saw in the history of the development of the parliamentary system in the Grand Duchy. It was this factor, and not the external situation, that turned out to be the most significant one for the conclusion of the Union of Lublin, apart from the efforts of the Lithuanian nobility to weaken the position of the magnates. The manner of understanding the history of Lithuanian statehood

${ }^{22}$ Павел Д. Брянцев, История Литовского государства с древнейших времен, Вильно 1889 [Pavel D. BRYANTSEv, Istoriya Litovskogo gosudarstva s drevneyshikh vremen, Vilno 1889].

${ }^{23}$ А. М. Столяров, ор.cit., p. 181. Cf. П. Д. Брянцев, ор.cit., p. 358.

${ }^{24}$ Николай А. Максимейко, Сеймы Литовско-Русского государства до Люблинской унии 1569 г., Харьков 1902 [Nikolay A. МАкsıмечко, Seymy Litovsko-Russkogo gosudarstva do Lyublinskoy unii 1569 g., Kharkov 1902].

${ }^{25}$ Матвей К. Любавский, Литовско-русский Сейм. Опьт по истории учреждения в связи с внутренним строем и внешней жизнью государства, Москва 1909 [Мatvey K. Lyubavskiy, Litovsko-russkiy Seym. Opyt po istorii uchrezhdeniya v svyazi s vnutrennim stroyem i vneshney zhiznyu gosudarstva, Moskva 1909]; idem, Очерк истории Литовско-Pусского государства до Люблинской унии включительно, Москва 1915 [Ocherk istorii Litovsko-Russkogo gosudarstva do Lyublinskoy unii vklyuchitelno, Moskva 1915].

${ }^{26}$ М. К. Любавский, Литовско-русский Сейм, р. 6. 
as the history of its representative bodies led to a corresponding understanding of the essence of the Union of Lublin, which, according to Lyubavskiy, was a parliamentary union and consisted in the establishment of a common Polish-Lithuanian parliament ${ }^{27}$.

Moving on to the concept of the Union of Lublin as presented in the work of I. Lappo, it should be noted that the historian devoted a large part of the first chapter (pp. 1-85) to the reconstruction of the Sejm of Lublin and the evaluation of the Act of the Union. The views that he expressed there should be briefly presented and then placed in the context of the general concept of I. Lappo's work, as well as in the context of Russian pre-revolutionary historiography.

Lappo starts his work with a general presentation of the provisions of the Act of the Union of Lublin. Basically, this description is quite a literal summary of the Act of the Union. After presenting the content of this document I. Lappo goes back in his narrative to the events from before July 1569 and describes the history of the union, taking the contraposition of the views of Poles and Lithuanians on the future union as the starting point. From the very beginning, Lappo observes not only the difference between the Polish and Lithuanian positions, but something more fundamental - the difference in the way of thinking about the union. The researcher distinguished three 'paths' leading to the conclusion of a union between Poland and Lithuania. In his opinion, the choice between them depended on the situation of both countries and the political wisdom of the partner that was stronger at a given moment ${ }^{28}$.

The 'path' that the Poles were going to follow was to demand that the old rights and privileges be exercised ${ }^{29}$. This way of proceeding, which consisted in forcing Sigismund Augustus to exercise its long held rights, was applied by the Crown nobility already at the Sejm in Warsaw of 1564, when "Поляки добились [underlined by the author - T.A.] от Сигизмунда Августа передачи наследственных прав на Княжество" ["Poles obtained the transfer of hereditary rights to the Duchy from Sigismund August"] although the Grand Duchy itself rejected the existence of such rights at all. The Poles acted similarly in 1569, when "заставили [underlined by the author - Т.А.] этого же государя отнять у Литвы Подляшье, Волынь и Киевщину и принудить Литовцев к проекту Унии" ["they forced the monarch to take Podlasie, Volhynia and Kiev regions from Lithuania and to impose a union project on the Lithuanians" ${ }^{30}$. According to the scholar, Poles considered the issue of

\footnotetext{
${ }^{27}$ А. М. Столяров, op.cit., p. 208.

${ }^{28}$ И. И. Лаппо, ор.cit., p. 23.

${ }^{29}$ Ibid., p. 8.

${ }^{30}$ Ibid., pp. 8-9.
} 
concluding a union as something that requires only energy, not creating a new legal situation ${ }^{31}$. Thus, they wanted to fully incorporate the Grand Duchy into the Crown and transform it into their own province ${ }^{32}$.

The approach of the Lithuanians towards the union was completely different, as they "were not against" the union, but only agreed to it on the condition that the dignity of the Grand Duchy of Lithuania would not be "humiliated" and that it would not suffer "umniejszenia i uszczerbku w tytule, prawach i dochodach" ["any denigration or prejudice in the title, rights and income"]

The 'path' that the Lithuanians intended to follow consisted in the rejection of all previous privileges and the conclusion of a new agreement. We should add that I. Lappo described these privileges as the “клятвопреступный хлам блестящих Ягеллонов” [“perjuring junk of the great Jagiellonians"] 34 and “гнилыми и позорными привилеями клятвопреступников-королей" ["rotten and shameful privileges of perjuring kings"]

The 'path' chosen by the Lithuanians was the only correct way to create a lasting union that would be willingly accepted by both sides. In its views, the Crown nobility completely ignored the course of the historical process and forgot that over the centuries the laws of the Lithuanian states had developed ${ }^{36}$. Yet according to I. Lappo, Lithuania had privileges granted by the Jagiellonians, which were in conflict with the aspirations of the Poles and defended the position of the Grand Duchy. The researcher mentioned here the privileges of 1452, 1492, 1506, 1529, a number of provisions of the Lithuanian Second Statute, and the provisions of the Sejm of Grodno of 1566. Besides, all these arguments were used at the Sejm of 1569 by the deputies and senators of the Grand Duchy of Lithuania.

Nevertheless, the Lithuanian arguments were completely rejected by the Poles. During the sessions of the Sejm of Lublin, it was a general practice for the Poles and Lithuanians to level a whole arsenal of arguments at each other, rejecting the privileges of the other party. Lappo claimed, however, that there was a whole difference of quality between them. Lithuanians pointed out that, under the law, the acts mentioned by Poles (such as the Privilege of Mielno from 1501 or the postponement of the Sejm of Warsaw of 1564) had no legal force ${ }^{37}$.

\footnotetext{
${ }^{31}$ Ibid., p. 9.

${ }^{32}$ Ibid., p. 14.

${ }^{33}$ Ibid., pp. 12-13.

${ }^{34}$ Ibid., p. 23.

${ }^{35}$ Ibid.

${ }^{36}$ Ibid., p. 11.

${ }^{37}$ Ibid., p. 22.
} 
Interestingly, in other places of his work Lappo generally noticed the diversity among the nobility of the Grand Duchy of Lithuania in religious ${ }^{38}$, social ${ }^{39}$, economic $^{40}$ and even political ${ }^{41}$ terms, considering it to be even greater than in Poland ${ }^{42}$. Nevertheless, in the description of the events of the Sejm of Lublin, the representatives of the Grand Duchy of Lithuania are treated as a rather homogeneous whole. What is more, in some places Lappo clearly emphasized the unity of views and actions of the Lithuanian elite ${ }^{43}$.

Typically, this issue has been resolved quite ambiguously in Russian historiography. S. Solovyov noticed the differences between the representatives of the Grand Duchy of Lithuania with regard to the Union, but he divided them mainly according to the ethnic criterion into the Lithuanian noblemen and the Ruthenian population ${ }^{44}$. Koyalovich made a different distinction, yet also according to ethnic criteria, between Lithuanian and Ruthenian nobility. Sigismund Augustus created a new political force from the former group, which became interested in the union with the Crown after it had received the rights of the Polish nobility ${ }^{45}$.

Some Russian historians noticed the differences between the magnates and the nobility of the Grand Duchy of Lithuania as regards the conclusion of a union with Poland. This was the case, for example, with K. Bestuzhev-Ryumin, but he did not draw any significant conclusions from this difference ${ }^{46}$. However, according to P. Bryancev, the magnates of the Grand Duchy of Lithuania were against the union, whereas the nobility supported it. Thus, the path to its conclusion was opened by the death of the voivode of Vilnius, Mikołaj 'the Black' Radziwiłł ${ }^{47}$. Fedor Ivanovich Leontovich had a rather equivocal stance in this matter: on the one hand he claimed that it was the magnates who strove for the Union of Lublin, as opposed to the appanage princes, whose existence he traced back to the $16^{\text {th }}$ century. On the other hand, he argued that the magnates stubbornly protested against the conclusion of the union ${ }^{48}$.

\footnotetext{
${ }^{38}$ Ibid., pp. 231-237.

${ }^{39}$ Ibid., pp. 254-255.

${ }^{40}$ Ibid., pp. $472-498$.

${ }^{41}$ Ibid., pp. 679-682.

${ }^{42}$ Ibid., p. 231.

${ }^{43}$ Ibid., p. 680.

${ }^{44}$ Cf. А. М. Столяров, ор.cit., p. 171.

${ }^{45}$ М. О. Коялович, Лекизии по истории Западной России, р. 200.

${ }^{46}$ К. Н. Бестужев-Рюмин, Русская история, p. 211. Cf. А. М. Столяров, ор.cit., p. 178.

${ }^{47}$ П. Д. Брянцев, ор.cit., p. 364.

${ }^{48}$ Федор И. Леонтович, Очерки истории литовско-русского права. Образование территории Литовского государства, Санкт-Петербург 1894 [Fedor I. Leontovich, Ocherki istorii litovsko-russkogo prava. Obrazovaniye territorii Litovskogo gosudarstva, Sankt-Peterburg
} 1894], p. 34. 
Lappo presented the argumentation of Poles in a completely different way. According to him, they rejected the Lithuanian arguments completely groundlessly, only because they were contrary to the interests of the Crown nobility. The actions of Poles were characterized by selectivity and "глубокий эгоизм и нежелание отступит от буквы старых, истлевших, заключенных в те времена, когда Литва была совсем не тою, какою она была в 1569 году, притом отчасти оспариваемых в формальном своем значении, как неутвержденные Литовцами, привилеев" [“Deep selfishness and unwillingness to give up the old, decayed privileges, conferred at a time when Lithuania was completely different from the Lithuania of 1569, partly contestable in the formal sense as they were not approved by the Lithuanians" ${ }^{49}$. The selfishness of Poles was stressed by I. Lappo on several occasions. He saw it in the discussions of the Crown nobility ${ }^{50}$ and in the disputes over the incorporation of the Kiev voievodship, when some senators believed that it should be left in the Grand Duchy of Lithuania only because its incorporation into the Crown would entail the need to incur expenses for defence ${ }^{51}$. Poles hid their selfishness under the hypocritical expressions of love, making sure, however, that Lithuanians would not see through their calculations and find out about the greed of their 'brothers' 52 .

The realisation of the Lithuanian 'path' to the union, considered by I. Lappo to be the right one, was the project of the union presented by the Grand Duchy. This project, although it involved making many concessions to the Poles, corresponded to the historical reality and to the status of the Grand Duchy of Lithuania and its government before $1569^{53}$. Its rejection was the reason for the Lithuanians' departure from Lublin, which, according to the scholar, was completely understandable in that context.

The Poles, on the other hand, did not want to achieve a real, fraternal union at all, but only to force the Lithuanians to conclude the Union ${ }^{54}$. This approach was completely inconsistent with the essence of the historical process, and thus, a fundamental mistake of Poles, who expressed an ill-conceived consent, short-sighted from the point of view of their interests, to retain the importance and rights of Lithuanian offices, without thinking about the content of this promise and not realizing how in this situation the details of the organization and activities of the joint Sejm should look like in reality.

\footnotetext{
${ }^{49}$ И. И. Лаппо, ор.cit., p. 17.

${ }^{50}$ Ibid., p. 14.

${ }^{51}$ Ibid., pp. 15, 40.

${ }^{52}$ Ibid., p. 16.

${ }^{53}$ Ibid., p. 26.

${ }^{54}$ Ibid., p. 51.
} 
Two features of I. Lappo's considerations are worth emphasizing here. First of all, he did not specify in his work what he really understood by 'historical reality', what meaning he gave to this term, and thus, what elements of this 'historical reality' meant that the conclusion of the union in the form proposed by the Poles did not correspond to the course of the 'historical process'.

Secondly, one should note a certain logical inconsistency in the historian's arguments. Since the 'historical reality' and the course of the 'historical process' made the full incorporation of Lithuania into the Crown impossible, the plans of Poles could not be realized, and the historical right was on the side of the Grand Duchy, in what other way (other than the one which the historian accused them of) could Poles carry out thoughtful and internally consistent actions consisting in the complete incorporation of Lithuania into the Crown and liquidation of its separateness, first of all its own system of offices?

When describing these 'paths' to the union and the position of the Poles, Lappo initially did not distinguish between the individual groups of representatives of the Crown. Only in the summary of this part of his deliberations does he add that the way of thinking he presented as 'Polish' was characteristic of the Chamber of Deputies. The Senate, on the other hand, 'sometimes tried to follow' the path of compromise, i.e. the implementation of old privileges, but with 'certain' concessions to Lithuania ${ }^{55}$.

More significant differences in the attitudes of the Chamber of Deputies and the Senate were made by Lappo only during the description of their activities after the Lithuanians left Lublin. It turned out that the Chamber of Deputies, in which the sentiments for the Lithuanians had deteriorated considerably, demanded that the Grand Duchy of Lithuania be forcibly annexed to the Crown. At the same time, the departure of the Lithuanians caused the Chamber of Deputies to openly disclose the demands for the detachment of Podlasie and Volhynia from the Duchy ${ }^{56}$. The Chamber of Deputies also demanded a pledge from the Lithuanian Deputy Chancellor, Ostafi Volovich, who had starosties in Podlasie, and who stayed in Lublin together with the Treasurer, Mikołaj Naruszewicz ${ }^{57}$. Taking advantage of the difficult situation of Lithuania and the resulting readiness to make concessions on its part, the deputies demanded that Lithuanians return to Lublin without convening sejmiks. This demand became a reason for I. Lappo to accuse the Chamber of Deputies of hypocrisy and utter contempt for the rights of the Grand Duchy of Lithuania ${ }^{58}$.

When drawing a picture of radical and hypocritical Chamber of Deputies, which insincerely pledged fraternal love to Lithuanians, I. Lappo was not

\footnotetext{
${ }^{55}$ Ibid., p. 23.

${ }^{56}$ Ibid., p. 27.

${ }^{57}$ Ibid., p. 30

${ }^{58}$ Ibid., p. 35.
} 
entirely consistent and at some point, quite inadvertently, weakened the coherence of such a negative description towards the deputies. He stated that the impatience of the deputies was partly justified by the prolonged works of the Sejm and the beginning of the period of agricultural works, which was the only source of income for the rank and file nobility ${ }^{59}$. Thus, in addition to subjective selfishness, Lappo introduced objective reasons explaining such behaviour of the deputies. However, this reference did not fundamentally change the picture of the activities of the Chamber of Deputies during the Sejm of Lublin.

In all the mentioned cases, the Senate proved far less radical than the deputies. Its strategy was to avoid open confrontation in order not to provoke outbursts of patriotism in Lithuanians ${ }^{60}$. As a result, the Senate, like Sigismund Augustus, did not initially demand a pledge from Volovich, but yielded to the pressure of the deputies. The Senate also made another attempt to calm the situation down and presented a compromise union proposal, which was rejected by the Chamber of Deputies as too favourable to the Grand Duchy. In the eyes of I. Lappo, this fact confirmed the righteousness of the Lithuanians ${ }^{61}$. The only attempt by the researcher to explain the reasons for the Senate yielding to the pressure from the deputies is the statement that in that era of the history of the Polish Sejm, it was not the Senate, but the Crown nobility that had the final word in it $^{62}$.

The description of Sigismund Augustus' actions is also quite symptomatic. Like his predecessors, he turned out to be a perjurer who, not caring about the rights and freedoms of Lithuanians and forgetting about the pledge given to the Grand Duchy with regard to decreasing its borders ${ }^{63}$, and more than that, by taking Volhynia and Podlasie away from Lithuania, he wanted to prove his decisiveness to "во что бы то ни стало держать руку Поляков и клятвопреступничать в их интересах, а не в интересах Княжества" ["take the Polish side regardless of any circumstances, and commit perjury in their interests, and not in the interests of the Duchy" ${ }^{64}$. Lappo assessed the monarch negatively, as "потерявшего почву под своими взглядами и убеждениями, разбитого развратом и пережитыми тяжелыми личными делами" ["the

${ }^{59}$ Ibid., p. 48.

${ }^{60}$ Ibid., p. 30.

${ }^{61}$ Ibid., p. 31.

${ }^{62}$ Ibid., pp. 31-32. By the way, it is worth noting that the idea that the Senate was pliable was in opposition to the view of N. Ustryalov (Н. Г. Устрялов, Русская история, ч. 1, p. 261) or P. Bryancev (П. Д. Брянцев, ор.cit., p. 364) that it was the Polish aristocracy that was particularly interested in concluding the union.

${ }^{63}$ И. И. Лаппо, ор.cit., p. 27.

${ }^{64}$ Ibid., p. 28. 
one who lost his bearings with regard to his views and beliefs, a man broken by debauchery and his dire personal experience"] ${ }^{65}$.

Basically, I. Lappo claimed that Sigismund Augustus was under the influence of Poles, and even that he sold himself to Poland ${ }^{66}$. However, when the historian described the events of the Sejm of Lublin in more detail, the monarch's attitude turned out to be, contrary to the general statements he used, much more complex. Like the Senate, Sigismund Augustus tried not to exacerbate the situation after the Lithuanians left Lublin and not to force Volovich to swear the pledge, although, again like the Senate, he finally yielded to the pressure of the deputies ${ }^{67}$. What is more, unlike the Senate, the king did not yield to the pressure of the Chamber of Deputies and in April convened Lithuanian sejmiks. Quite suprisingly, I. Lappo's explanation of the monarch's decision was that Sigismund Augustus, in his decisions concerning the Grand Duchy of Lithuania, was able not to take into account the will of the Polish $\mathrm{Sejm}^{68}$. On 27 June, in the speech given by Deputy Chancellor of the Crown, Franciszek Krasiński, the king even promised the Lithuanians that in time it would be possible to make changes in the union's conditions. I. Lappo particularly emphasized this moment, as it allowed him to legitimize the subsequent actions of the Lithuanians ${ }^{69}$.

Moreover, in some parts of his work it turned out that Sigismund Augustus did not always despise the pledges given to Lithuanians. On 9 July he proposed a division of the competences of the Marshal offices, which was quite favourable for Lithuania, as well as alternate convocation of Sejm sessions in the Grand Duchy and the Crown, justifying this proposal by a pledge given to the Lithuanians ${ }^{70}$. At the same time, the king was aware of the injustice done to Lithuania by the separation of Podlasie, Volhynia, Kiev and Bracław land, and during the Sejm of 1572 he offered to hand over Mazovia to Lithuania in return.

It is worth noting that the way of explaining the motives behind the behaviour of Sigismund Augustus and, more broadly, his predecessors, was characteristic of a large part of Russian pre-revolutionary historiography, which traditionally accused the Jagiellonians (including Jogaila, who concluded the Union of Krevo) of betraying Lithuania and perjury ${ }^{71}$. At the same time, it

${ }^{65}$ Ibid., pp. 23-24.

${ }^{66}$ Ibid., p. 111.

${ }^{67}$ Ibid., p. 30.

${ }^{68}$ Ibid., p. 37.

${ }^{69}$ Ibid., p. 58.

${ }^{70}$ Ibid., p. 65.

${ }^{71}$ Cf. Сергей М. Соловьев, Очерк истории Малороссии до подчинения её изарю Алексею Михайловичу, Отечественные записки, т. 61: 1848, no. 11 [Sergey M. Solovyev, Ocherk 
was Sigismund Augustus who was often considered one of the main, if not the most important, supporters of the union ${ }^{72}$. In some cases, as in the example of N. Ustryalov, this was due to the manner of understanding the historical process, in which the rulers remained the main actors in the course of history ${ }^{73}$.

The actions of Sigismund Augustus become one of the two most important reasons for the conclusion of the Union of Lublin in the narrative of I. Lappo. The second reason was the difficult situation of the Grand Duchy of Lithuania in the international arena ${ }^{74}$, namely a pressure exerted simultaneously by Moscow and the Tatars ${ }^{75}$. The situation of Lithuania was aggravated by the separation of Podlasie and Volhynia, which deprived it of significant material and military resources ${ }^{76}$. The fact that the Grand Duchy was in a difficult situation and that Lithuania was ready to accept the Polish conditions was confirmed, according to the researcher, by the Lithuanian message read out at the Sejm on 5 April $^{77}$. All this was well known to Poles who, taking advantage of their influence on the king, used the difficult situation of Lithuania as an element of leverage to conclude the union ${ }^{78}$.

It is worth noting that the international situation of the Grand Duchy of Lithuania was not initially considered by Russian historiography as the cause of the Union of Lublin, because the threat from Moscow, the Livonian War, did not fit into the dualistic concept of the development of Ruthenia. Hence the lack of indication of this reason by N. Ustryalov or even S. Solovyov, although the latter considered the international context to be one of the factors of historical development ${ }^{79}$.

The factor of the Tatar and, partly, Muscovite threat appeared in the deliberations of M. Koyalovich ${ }^{80}$ and was substantiated by D. Ilovayski, who claimed that the nobility of the Grand Duchy of Lithuania feared the tyranny of Ivan 'the Terrible ${ }^{81}$. The importance of the Livonian War was particularly

istorii Malorossii do podchineniya eye tsaryu Alekseyu Mikhaylovichu, Otechestvennyye zapiski, vol. 61: 1848, no. 11], p. 21.

${ }^{72}$ Н. Г. Устрялов, Русская история, ч. 1, р. 261; М. О. Коялович, Лекици по истории 3ападной России, р. 205; Дмитрий И. Иловайский, История России, Т. 3: Московско-иарский период, Москва 1890 [Dmitriy I. ILovaYsкiY, Istoriya Rossii, vol. 3: Moskovsko-tsarskiy period, Moskva 1890], p. 148.

${ }^{73}$ А. М. Столяров, ор.cit., p. 169.

${ }^{74}$ И. И. Лаппо, ор.cit., p. 15.

${ }^{75}$ Ibid., p. 24.

${ }^{76}$ Ibid., p. 28.

${ }^{77}$ Ibid., p. 35.

${ }^{78}$ Ibid., p. 15.

${ }^{79}$ А. М. Столяров, ор.cit., p. 172.

${ }^{80}$ М. О. Коялович, Лекиии по истории Западной России, р. 198.

${ }^{81}$ Д. И. Иловайский, История России, Т. 3: Московско-изарский период, р. 148. 
emphasised by M. Lyubavskiy, who also said that it was conducive to the growth of the political significance of the nobility ${ }^{82}$.

A description of the works on the Act of the Union and its adoption, which is in fact a detailed description of disputes over the conclusion of the Act of the Union of 1 July and even disputes during the oath, is a significant part of I. Lappo's work ${ }^{83}$. The same applies to the description of the subsequent sittings of the Sejm after the conclusion of the Union. The historian noted that disputes between Poles and Lithuanians in the Chamber of Deputies arose practically at once. They related to the seats of particular voivodeships and the competences of Lithuanian offices, especially marshals, which, according to the scholar, clearly showed the differences in the interests and attitudes of both nations ${ }^{84}$.

Lappo also analysed the way in which the representatives of Lithuania and the Crown participated in the consideration of two categories of matters: issues concerning the whole state and problems concerning only one of its components.

As far as the national issues are concerned, the historian discussed the issue of organising a defence against Moscow. This is one of the few cases in the description of the events of the Sejm of Lublin, where he noticed the differences between Lithuanians themselves, whom so far he had presented to be completely unanimous. In this case, it turned out that while Lithuanian deputies wanted to be exempted from defence taxes, demanding equal rights with Poles, who did not have to incur regular expenses for the army due to the quarter tax, the senators of the Grand Duchy sought to prevent the introduction of the quarter tax in Lithuania ${ }^{85}$.

However, the main part of the narrative was devoted to the disputes between Lithuanians and Poles. According to the historian, it turned out that even on such an important issue as the defence of the borders of a common state, there were fundamental differences between both parts of the state: different tax systems and tax collection, as well as different interests of Poland and Lithuania. These differences were so far-reaching that they called into question the unity of the common state ${ }^{86}$. Despite concluding the Union, the unity of the Polish-Lithuanian Commonwealth turned out to be illusory, and what triumphed in the Sejm were the selfish interests of both its constituent parts. At the same time, the Crown itself, by defending its own interests, refusing to transfer quarter tax funds to the defence of Lithuania and emphasizing

\footnotetext{
${ }^{82}$ М. К. Любавский, Очерк истории Литовско-Русского государства, р. 246.

${ }^{83}$ И. И. Лаппо, ор.cit., pp. 48-63.

${ }^{84}$ Ibid., pp. 63-64.

${ }^{85}$ Ibid., p. 71.

${ }^{86}$ Ibid., p. 73.
} 
its 'own' defence, set an obstacle to full unification with the Grand Duchy of Lithuania ${ }^{87}$.

A similar conclusion was drawn by I. Lappo from his analysis of the way in which the representatives of Lithuania and the Crown participated in the Sejm considerations with regard to matters concerning only particular parts of the Polish-Lithuanian Commonwealth. It turned out, as the researcher claimed, that the participation of Lithuanians in the works of the Sejm was limited only to common issues and matters related to the Grand Duchy of Lithuania, but they did not participate in the considerations of Crown problems. Similarly, Poles were not interested in Lithuanian issues. The historian pointed out a number of cases when the matters of Grand Duchy of Lithuania were discussed by Lithuanians themselves ${ }^{88}$. The researcher concluded that Lithuania was 'apart', as it self-handedly debated its own affairs and prepared its constitutions which were read in the Chamber of Deputies already finished (that is not working on them with the Crown deputies); only in the case when they were in conflict with the Crown constitutions did the procedure of coordination take place. Instead of striving for unity, the Sejm of Lublin once again revealed the egoistic aspirations of both parts of the Polish-Lithuanian Commonwealth to take care exclusively of their own interests. Even the very reading of the constitution transformed into a quarrel and a manifestation of mutual distrust $\mathrm{t}^{89}$.

A question needs to be asked about the aim of such a long reconstruction of the events of the Sejm of Lublin. The scholar himself indicated that this was to clarify the ground for Polish-Lithuanian relations in the following decades $^{90}$. In reality, however, one could guess that the goal he was pursuing was slightly different. The indication of a long series of differences and disputes between the Crown and the Grand Duchy of Lithuania, and the selfishness of Poles, which, according to I. Lappo, was revealed during the Sejm and in the moment of concluding the Union, was to be a clear proof of the existence of a strong sense of distinctiveness in both parts of the Polish-Lithuanian Commonwealth.

This is how the construction of I. Lappo's description of the Sejm of Lublin was supposed to prove the basic thesis of the researcher: preservation of the distinctiveness of the Grand Duchy of Lithuania and the Crown after the conclusion of the Union of Lublin. At the same time, Lappo stated: “Отдельность Литвы от Польши, так резко провозглашаемая реальною действительностью, несмотря на звучащее фальшивым звуком оффициальной лжи

\footnotetext{
${ }^{87}$ Ibid., p. 73.

${ }^{88}$ Ibid., p. 74.

${ }^{89}$ Ibid., p. 78.

${ }^{90}$ Ibid., p. 79.
} 
заявление акта Унии, что оба государства составляют «jedno ciało», единое тело, подчеркивается и сохранением Литовских должностей в их значении на спольном сейме, что делало и самый сейм не Коронным, как его обозначает договор Унии, а Польско-Литовским сеймом соединенных представителей двух отдельных частей государства” [“Lithuania's separateness from Poland, so sharply proclaimed in reality, despite the apparently false sound of the official declaration of the union act that both countries formed 'one body' was emphasised also by the preservation of the importance of Lithuanian offices at the common Sejm, which made the common Sejm no longer a Crown parliament, as defined by the Union Agreement, but a Polish-Lithuanian Parliament of the combined representatives of two separate parts of the State" $]^{91}$.

Lappo observed that the striving to leave separate Lithuanian offices was dictated not only by the idealistic defence of dignity and significance of the Grand Duchy of Lithuania, but also by a completely material desire of the Lithuanians to defend their own posts. However, it was this striving that, regardless of its motives, protected Lithuania from being completely incorporated into the Crown to a large extent ${ }^{92}$.

Paradoxically, the Sejm of Lublin further strengthened the sense of Lithuanian identity by making the selfishness of Poles clearly visible. The attitudes of the representatives of both parts of the Polish-Lithuanian Commonwealth turned out to be completely opposite: “С одной стороны эгоизм и холодный разсчет рядом с заносчивостью чувствующего за собою силу момента и обстоятельств эгоиста, с другой-кровавые слезы и безысходное горе истинного страдания людей, находящихся в безвыходном положении" ["On the one hand, selfishness, cold reckoning and arrogance of a selfish opportunist, and on the other, blood tears and hopeless pain and misery of people who found themselves in a situation of no return" ${ }^{93}$.

It should be noted that the reconstruction of the events of the Sejm of Lublin made by I. Lappo was based mainly on the journal published by M. Koyalovich ${ }^{94}$. It is symptomatic that after that journal also content of many documents was cited. Other sources that were used in the work were rather scant and among them were exclusively published sources. They included: the documents of the sejmik campaign of April-June 1569 (broadly summarized) from the Lithuanian Metrica published by Lyubavskiy ${ }^{95}$; letters from Mikołaj

\footnotetext{
${ }^{91}$ Ibid., p. 80.

${ }^{92}$ Ibid., pp. $80-81$.

${ }^{93}$ Ibid., p. 82.

${ }_{94}$ Дневник Люблинского сейма, passim.

${ }_{95}$ М. К. Любавский, Литовско-русский Сейм. Приложения, рр. 215-225.
} 
Naruszewicz, Erasmus Kroczewski and Jan Chodkiewicz to Mikołaj Krzysztof Radziwiłł and from Mikołaj Naruszewicz to Mikołaj Radziwiłł from July ${ }^{96}$; and the privilege issued by Sigismund Augustus on 19 July 1569 concerning the division of the competences of the Marshal offices ${ }^{97}$.

To sum up our considerations, it should be noted that the study of the Union of Lublin was not an end goal for I. Lappo in itself. The main object of his research were issues we may nowadays describe as constitutional, including the status of the Grand Duchy of Lithuania within the Polish-Lithuanian Commonwealth after 1569. Therefore, it is difficult to expect a versatile analysis of the reasons for concluding the Union or a detailed reconstruction of the course of events during the Sejm of Lublin from his works. Nevertheless, the description of the conclusion of the Union and its context remained extremely important to him because of his desire to clarify the attitude of Lithuanians towards Poles and the legal relationship between the Grand Duchy of Lithuania and the Crown. No wonder, therefore, that in his deliberations he devoted much of his attention to the Union of Lublin without treating it as a direct subject of his research.

According to I. Lappo, it was the Poles that were the more active subject in strive for the union, especially the Chamber of Deputies, which was the most radical in its demands and the least willing to compromise, and yet, at the same time, the most emotionally responsive to the events. The Senate was more flexible and willing to compromise. Lappo did not make any special distinctions within the Chamber of Deputies and the Senate, according to any other criteria (regional origin, religion, social and property status, etc.). Sigismund Augustus, on the other hand, in the pages of the publication under discussion, appeared as a monarch who succumbed to the influence of Poles, deprived of his own initiative, and breaking his earlier pledges, although, as indicated above, his image in the deliberations of I. Lappo did not always remain coherent.

There is no doubt that the researcher had a negative attitude towards the Union of Lublin. I. Lappo clearly took the side of the Lithuanians, whom he presented in a number of places as caring only for the preservation of the current state of affairs, and at the same time, contrary to Poles and Sigismund

${ }^{96}$ Published in: Археографический сборник документов, относящихся к истории Северо-Западной Руси, Т. 7, Вильна 1870 [Arheograficheskij sbornik dokumentov, otnosyashchihsya k istorii Severo-Zapadnoj Rusi, vol. 7, Vil'na 1870], pp. 34-49 (documents no. 19-27). On the basis of considerations regarding the date of the letter no. 27 (M. Naruszewicz to M. Radziwiłł) (И. И. Лаппо, ор.cit., p. 67, footnote 2), it is quite apparent that Lappo only used the publication, and not the manuscript.

${ }^{97}$ Published in: Zbiór Pamiętników do dziejów Polskich, ed. Włodzimierz S. DE BRUEL-Plater, vol. 2, Warszawa 1868, pp. 17-18. 
Augustus, as not committing evil and unworthy acts dictated solely by their own selfishness, to the detriment of others.

In this respect, the position of I. Lappo was typical of Russian historiography as, since the publications of N. Ustryalov, it had viewed the Grand Duchy of Lithuania as a state that belonged to Russian tradition, as opposed to Poland, which was different both culturally and civilisationally.

Significantly, I. Lappo still used the term 'Lithuanian-Ruthenian' to describe the Grand Duchy of Lithuania, its society and institutions. What is important, it was not meant to be any radical emphasis of the 'Ruthenian' character of the state whatsoever. Of the elements that testify to the latter, he only mentioned the Ruthenian language, which he named among the elements defining the nobility of the Grand Duchy of Lithuania ${ }^{98}$.

However, in contrast to many other representatives of Russian historiography ${ }^{99}$, the work of Lappo does not present the history of the Polish-Lithuanian union as the history of struggle between Catholicism and Eastern Orthodoxy. With a few exceptions, such as the description of the controversy over the pledge made by the Arians on 1 July, the historian did not analyse religious affiliations of individual representatives of Lithuania and the Crown when describing the events of the Sejm of Lublin.

This does not mean, however, that the religious issues were completely alien to him. Within the framework of the deliberations on the nobility of the Grand Duchy and its distinctiveness from the Crown nobility, in the second chapter of the work, I. Lappo pointed to greater religious diversity in Lithuania than in Poland, and to the role played by Orthodox Christians in the Grand Duchy of Lithuania. However, it is symptomatic that when describing the significance of Protestantism in Lithuania, he states that its role was to undermine the privileged position of Catholicism in the Grand Duchy of Lithuania and to make all religions equal, including Eastern Orthodoxy, in the rights. The introduction of a similar element to the considerations made I. Lappo, willingly or unwillingly, abandon the construct of understanding the Polish-Lithuanian union as a history of struggle between Catholicism and Eastern Orthodoxy, which was so frequently used in Russian historiography.

${ }^{98}$ И. И. Лаппо, ор.cit., p. 238.

${ }^{99}$ It is worth noting that this pattern also occurred with historians of substantially different views. Cf. Николай А. Полевой, История русского народа, Т. 5, Москва 1833 [Nikolay A. Polevoy, Istoriya russkogo naroda, vol. 5, Moskva 1833], p. 166; Н. Г. Устрялов, Русская история, ч. 1, р. 177; Николай П. Дашкевич, Заметки по истории Литовско-Русского государства, Киев 1885 [Nikolay P. DASHкEvich, Zametki po istorii Litovsko-Russkogo gosudarstva, Kiyev 1885], p. 119; А. М. Столяров, ор.cit., pp. 163-179. 
The fundamental novelty was the justification of the most important thesis for the historian, namely the claim that the Grand Duchy of Lithuania maintained its distinctiveness after 1569. Apparently, it was in support of this thesis that the author wrote his deliberations on the circumstances of concluding the Union of Lublin. All the observations made in the article lead to the conclusion that the scholar's work contains innovative and ground-breaking findings, as well as elements which are a continuation of the traditional narrative of the Russian pre-revolutionary historiography.

Translated by Tomasz Leszczuk

Received 15 May 2019

Received in revised form 1 August 2019

Accepted 10 December 2019

Dr Tomasz Ambroziak

Laboratory for Studying Primary Sources

Ural Federal University, Yekaterinburg, Russia

e-mail: tomasz.ambr@gmail.com

ORCID ID: 0000-0002-0125-6011

\section{IVAN IVANOVICH LAPPo's VIEWS}

on the Circumstances of Establishing the Union of Lublin

in the Context of Pre-Revolutionary Russian Historiography

\section{Abstract}

Key words: Polish-Lithuanian Commonwealth, Grand Duchy of Lithuania, Union of Lublin, Ivan Ivanonich Lappo, Russian historiography, history of historiography

The aim of the article is to analyze the views of Ivan Ivanovich Lappo regarding the circumstances of the conclusion of the Union of Lublin. The opinions of this historian were presented in the context of the views of Russian pre-revolutionary historiography, especially of such authors as Nikolay Gerasimovich Ustryalov, Mikhail Osipovich Koyalovich, Nikolay Alexeyevich Maksimieyko, Matvey Kuzmich Lyubavskiy and Fedor Ivanovich Leontovich. The article belongs to the vast area of studies on the history of historiography, the undertaking of which allows the assessment of the current scholarly achievements and research methodology, and thus making new research postulates.

It should be noted that, despite some evolution, the fundamental assessment of the Union of Lublin in Russian pre-revolutionary historiography remained negative. However, the circumstances and reasons for its conclusion were perceived differently. 
Although the description of the conclusion of the Union of Lublin was not the main research goal for I. Lappo, he carried out a fairly detailed reconstruction of the Sejm of Lublin and the circumstances of the conclusion of the Polish-Lithuanian union in 1569. It seems that the aim of such a procedure was not only to explain the attitude of Lithuanians towards Poles and the legal relationship between the Grand Duchy and the Crown, but first of all to support of the historian's fundamental thesis that, as a result of the Union of Lublin, the Grand Duchy did not lose its independence and distinctiveness.

This historian not only reported the course of the Sejm of Lublin and the decision of the Act of the Union of July 1, but also confronted the views of Poles and Lithuanians concerning the conditions of the Union and the way it was concluded. According to him, the historical reality and the political system of the Grand Duchy until 1569 corresponded to the project of a union presented by Lithuanians. In his opinion, the aim of Poles was not to bring about real unification based on the principles of equality and fraternity, but to force Lithuanians to enter into a union through the implementation of old rights and privileges. In some parts of his research, however, the scholar differentiated between the radical attitude of the Chamber of Deputies of the Crown and the more conciliatory position of the Senate.

The description of King Sigismund Augustus's activities presented by I. Lappo turned out to be quite paradoxical and partly incoherent. On the one hand, the historian claimed that the monarch was under the influence of Poles and betrayed the Grand Duchy. On the other hand, he quoted a number of cases in which the king's attitude contradicted this general opinion.

Lappo's general attitude towards the Union of Lublin remained negative. The historian clearly sympathized with Lithuanians, seeing Poles as merely caring for their own interests to the detriment of the Grand Duchy. The analysis of Lappo's views made in this article shows that there are elements in his concepts that testify to the connection with the traditional narrative of Russian historiography, as well as new and original ideas.

\author{
Die Ansichten Ivan Ivanovich Lappos \\ ÜBER DIE UMSTÄNDE DES ABSCHLUSSES DER Lubliner UNION IM KonTEXT \\ DER VORREVOLUTIONÄREN RUSSISCHEN GESCHICHTSSCHREIBUNG
}

\begin{abstract}
Schlüsselwörter: polnisch-litauische Republik, Großherzogtum Litauen, Lubliner Union, Ivan Ivanovich Lappo, russische Geschichtsschreibung, Geschichte der Geschichtsschreibung

Das grundsätzliche Ziel des vorliegenden Textes ist die Analyse der Ansichten von Iwan Iwanowicz Łappo bezüglich der Umstände, unter denen die Union von Lublin abgeschlossen wurde. Die Meinungen dieses Historikers wurden im Kontext
\end{abstract}


der russischen vorrevolutionären Geschichtsschreibung geschildert, insbesondere von Autoren wie Nikolaj Gierasimowicz Ustriałow, Michail Osipowicz Kojałowicz, Nikolaj Aleksiejewicz Maksimiejko, Matfiej Kuzmicz Lubawski oder auch Fiodor Iwanowicz Leontowicz. Der Artikel fügt sich in die Forschungsströmung zur Geschichte der Geschichtsschreibung ein, dank welcher die bisherigen wissenschaftlichen Errungenschaften und die Forschungsmethodologie bewertet und so neue Forschungspostulate definiert werden können.

Beachtenswert ist dabei, dass die grundsätzliche Beurteilung der Union von Lublin in der russischen vorrevolutionären Geschichtsschreibung trotz einer gewissen Evolution negativ blieb. Die Umstände und Ursachen ihres Abschlusses wurden von ihr aber unterschiedlich ausgewertet.

Obwohl die Darstellung des Abschlusses der Lubliner Union für I. Łappo kein eigenständiges Forschungsziel war, rekonstruierte er den Verlauf des Sejms von Lublin und die Umstände des Abschlusses der polnisch-litauischen Union im Jahre 1569 recht ausführlich. Es scheint, dass der Historiker nicht nur die Einstellung der Litauer zu den Polen und das Rechtsverhältnis zwischen dem Großherzogtum Litauen und der polnischen Krone erklären, sondern vor allem seine grundsätzliche These stützen wollte, nach der das Großherzogtum Litauen infolge der Lubliner Union seine Eigenständigkeit und Unterscheidbarkeit nicht verloren habe.

Der Geschichtswissenschaftler berichtet nicht nur über den Verlauf des Lubliner Sejms und die Bestimmungen des Unionvertrags vom 1. Juli, sondern konfrontiert auch die Ansichten der Polen und der Litauer hinsichtlich der Bedingungen des Unionsvertrags und der Umstände seines Abschlusses miteinander. Ihm zufolge entspricht das von den Litauern vorgestellte Projekt der Union der historischen Realität und der Staatsform des Großherzogtums Litauen bis 1569.

Das Ziel der Polen habe nicht darin bestanden, eine reale Vereinigung auf der Grundlage der Grundsätze von Gleichheit und Brüderlichkeit herbeizuführen, sondern die Litauer dazu zu zwingen, auf dem Wege der Durchsetzung alter Rechte und Privilegien eine Union einzugehen. An bestimmten Stellen differenziert der Forscher jedoch zwischen der radikalen Haltung der Abgeordnetenkammer der Krone und der versöhnlicheren Haltung des Senats.

Die von I. Łappo dargestellte Beschreibung der Handlungen von Sigismund II. August erweist sich als ziemlich paradox und teilweise inkohärent. Einerseits behauptet der Historiker, der Monarch habe unter polnischem Einfluss gestanden und das Großherzogtum verraten. Andererseits führt er eine Reihe von Fällen an, in denen die Haltung des Königs dieser allgemeinen Meinung widerspricht.

I. Łappos Grundhaltung gegenüber der Lubliner Union bleibt aber negativ. Der Historiker sympathisiert eindeutig mit den Litauern und ist der Überzeugung, die Polen hätten sich lediglich um ihre eigenen Interessen gekümmert, zum Nachteil des Großherzogtums.

Die Analyse der Ansichten von I. Łappo in diesem Artikel zeigt, dass sein Konzept sowohl Elemente umfasst, die einen Zusammenhang mit der traditionellen Erzählung der russischen Geschichtsschreibung belegen, als auch völlig neue und originelle Ideen. 


\author{
Poglądy IWANA IWANOWICZA ŁAPPY \\ NA OKOLICZNOŚCI ZAWARCIA UNII LUBELSKIEJ \\ W KONTEKŚCIE PRZEDREWOLUCYJNEJ HISTORIOGRAFII ROSYJSKIEJ
}

\begin{abstract}
Abstrakt
Słowa kluczowe: Rzeczpospolita Obojga Narodów, Wielkie Księstwo Litewskie, unia lubelska, Iwan Iwanowicz Łappo, historiografia rosyjska, historia historiografii
\end{abstract}

Celem artykułu jest analiza poglądów Iwana Iwanowicza Łappy dotyczących okoliczności zawarcia unii lubelskiej. Opinie tego historyka zaprezentowano w kontekście poglądów przedrewolucyjnej historiografii rosyjskiej, szczególnie takich autorów, jak Nikołaj Gierasimowicz Ustriałow, Michaił Osipowicz Kojałowicz, Nikołaj Aleksiejewicz Maksimiejko, Matfiej Kuzmicz Lubawski czy Fiodor Iwanowicz Leontowicz. Artykuł wpisuje się w nurt studiów nad historią historiografii, których podjęcie pozwala na ocenę dotychczasowego dorobku nauki i metodologii badań, a przez to postawienie nowych postulatów badawczych.

Należy zauważyć, że mimo pewnej ewolucji zasadnicza ocena unii lubelskiej w przedrewolucyjnej historiografii rosyjskiej pozostawała negatywna. Różnie jednak postrzegano w niej okoliczności i przyczyny jej zawarcia.

Mimo że opis zawarcia unii lubelskiej nie był dla I. Łappy samoistnym celem badań, dokonał on dość szczegółowej rekonstrukcji przebiegu sejmu lubelskiego i okoliczności zawarcia unii polsko-litewskiej w 1569 r. Wydaje się, że celem podobnego zabiegu była nie tylko chęć wyjaśnienia stosunku Litwinów do Polaków oraz stosunku prawnego pomiędzy Wielkim Księstwem i Koroną, lecz przede wszystkim wsparcie zasadniczej tezy historyka o tym, że wskutek unii lubelskiej Wielkie Księstwo nie utraciło samodzielności i odrębności.

Historyk ten nie tylko zreferował przebieg sejmu lubelskiego i postanowienia aktu unii z 1 lipca, ale też skonfrontował poglądy Polaków i Litwinów na warunki unii oraz sposób jej zawarcia. Według niego rzeczywistości historycznej oraz ustrojowi Wielkiego Księstwa do 1569 r. odpowiadał projekt unii przedstawiony przez Litwinów. Celem Polaków było zaś niedoprowadzenie do realnego zjednoczenia, opierając się na zasadzie równości i braterstwa, lecz zmuszenie Litwinów do zawarcia unii w drodze realizacji dawnych praw i przywilejów. W poszczególnych miejscach badacz dokonywał jednak zróżnicowania pomiędzy radykalną postawą koronnej izby poselskiej a bardziej ugodowym stanowiskiem senatu.

Przedstawiony przez I. Łappę opis działań Zygmunta Augusta okazał się dość paradoksalny i częściowo niespójny. Z jednej strony historyk twierdził, że monarcha znajdował się pod wpływem Polaków i dokonał zdrady Wielkiego Księstwa. Z drugiej strony przytaczał on szereg przypadków, w których postawa króla przeczyła tej ogólnej opinii.

Zasadniczy stosunek I. Łappy do unii lubelskiej pozostawał negatywny. Historyk wyraźnie sympatyzował z Litwinami, Polaków postrzegając jako dbających jedynie o własne interesy ze szkodą dla Wielkiego Księstwa. Dokonana w niniejszym arty- 
kule analiza poglądów I. Łappy pozwala stwierdzić istnienie w jego koncepcji zarówno elementów świadczących o związku z tradycyjną narracją rosyjskiej historiografii, jak i nowych, oryginalnych idei.

\section{BIBLIOGRAPHY}

Bestuzhev-Ryumin, Konstantin N. Russkaya istoriya, vol. I-II. Sankt-Peterburg: Izd. D. E. Kozhanchikova. Tip. A. Transhelya, 1872-1885.

Błachowska, Katarzyna. Wiele historii jednego państwa. Obraz dziejów Wielkiego Księstwa Litewskiego do 1569 roku w ujęciu historyków polskich, rosyjskich, ukrainskich, litewskich i białoruskich w XIX wieku. Warszawa: Wydawnictwo Neriton, 2009.

Błaszczyk, Grzegorz. Dzieje stosunków polsko-litewskich, vol. 2/1: Od Krewa do Lublina. Poznań: Wydawnictwo Poznańskie, 2007.

Bryantsev, Pavel D. Istoriya Litovskogo gosudarstva s drevneyshikh vremen. Vilno: Tipografiya A. G. Syrkina, 1889.

Cherepitsa, Valeriy N. Mikhail Osipovich Koyalovich. Istoriya zhizni i tvorchestva. Grodno: Grodnenskiy gosudarstvennyy universitet, 1998.

Chernobayev, Anatoliy A. "Koyalovich Mikhail Osipovich." In Istoriki Rossii. Biografii, 223-228. Moskva: ROSSPEN, 2001.

Czerniecka-Haberko, Anna. Unie polsko-litewskie w historiografii polskiej. Toruń: Adam Marszałek, 2013.

Dashkevich, Nikolay P. Zametki po istorii Litovsko-Russkogo gosudarstva. Kiyev: Tip. Imp. Un-ta sv. Vladimira, 1885.

Dovnar-Zapolskiy, Mitrofan V. "Spornyye voprosy v istorii Litovsko-Russkogo seyma." Zhurnal ministerstva narodnogo prosveshcheniya 10 (1901): 454-498.

Dovnar-Zapolskiy, Mitrofan V. Gosudarstvennoye khozyaystvo Velikogo knyazhestva Litovskogo pri Yagelonakh. Kiyev: Tipografiya Imperatorskogo Universiteta Sv. Vladimira V. I. Zavadskogo, 1901.

Dovnar-Zapolskiy, Mitrofan V. Polsko-Litovskaya uniya na seymakh do $1569 \mathrm{~g}$. Istoricheskiy ocherk. Moskva: Tipografiya G. Lissnera i A. Geshelya, 1897.

Dubyeva, Lyudmila. “'Otdayus nauke sovsem.... I. I. Lappo - professor russkoy istorii Tartuskogo (Yuryevskogo) universiteta v 1905-1918 gg." In Baltiyskiy arkhiv. Russkaya kultura v Pribaltike, vol. 9, edited by Pavel Lavrinets, 374-391. Vilnyus: Russkiye tvorcheskiye resursy Baltii, Kafedra russkoy filologii Vilnyusskogo universiteta, 2005.

Dvornichenko, Andrey Y. "Istoriografiya Velikogo knyazhestva Litovskogo i 'Ocherk istorii Litovsko-Russkogo gosudarstva’ M. K. Lyubavskogo.” Trudy Istoricheskogo fakulteta Sankt-Peterburgskogo universiteta 12 (2013): 97-120.

Gorizontov, Leonid E. "Zapadnorusizm v mire identichnostey mezhslavyanskogo pogranichia. Istoriograficheskiye nablyudeniya.” In Slavyanskiy mir. V poiskakh identichnosti, 930-939. Moskva: Institut slavyanovedeniya RAN, 2011.

Ilovayskiy, Dmitriy I. Istoriya Rossii, vol. 3: Moskovsko-tsarskiy period. Moskva: Tipografiya M. G. Volchaninova, 1890. 
Jučas, Mečislovas. Unia polsko-litewska. Toruń: Europejskie Centrum Edukacyjne, 2004.

Karamzin, Nikolay M. Istoriya gosudarstva Rossiyskogo, vol. I-XII. Sankt-Peterburg: Tip. N. Grecha, 1818-1829.

Koyalovich, Mikhail O. Istoricheskoye issledovaniye o Zapadnoy Rossii, sluzhashcheye predisloviyem $k$ dokumentam, obyasnyayushchim istoriyu zapadnorusskogo kraya i ego otnosheniya $k$ Rossii i $k$ Polshe. Sankt-Peterburg: Tip. Pratsa, 1865.

Koyalovich, Mikhail O. Lektsii po istorii Zapadnoy Rossii. Moskva: Tip. Bakhmeteva, 1864.

Koyalovich, Mikhail O. Lyublinskaya uniya, ili posledneye soyedineniye litovskogo knyazhestva s polskim. Sankt-Peterburg: Izdaniye redaktsii gazety „Russkiy invalid”, 1863.

Lappo, Ivan I. Velikoye knyazhestvo Litovskoye za vremya ot zaklyucheniya Lyublinskoy Unii do smerti Stefana Batoriya. Sankt-Peterburg: Tipografiya I. N. Skorokhodova, 1901.

Leontovich, Fedor I. Ocherki istorii litovsko-russkogo prava. Obrazovaniye territorii Litovskogo gosudarstva. Sankt-Peterburg: Tipografiya V. S. Balasheva i Ko, 1894.

Lyubavskiy, Matvey K. Litovsko-russkiy Seym. Opyt po istorii uchrezhdeniya v svyazi s vnutrennim stroyem i vneshney zhiznyu gosudarstva. Moskva: Universitetskaya tipografiya, 1909.

Lyubavskiy, Matvey K. Ocherk istorii Litovsko-Russkogo gosudarstva do Lyublinskoy unii vklyuchitelno. Moskva: Moskovskaya khudozhestvennaya pechatnya, 1915.

Maksimeyko, Nikolay A. Seymy Litovsko-Russkogo gosudarstva do Lyublinskoy unii $1569 \mathrm{~g}$. Kharkov: Tipografiya Adolfa Darre, 1902.

Michaluk, Dorota. “Unia lubelska w polskiej historiografii XIX i XX wieku.” In Unia lubelska $z 1569$ roku. Z tradycji unifikacyjnych I Rzeczypospolitej, edited by Tomasz Kempa and Krzysztof Mikulski, 151-184. Toruń: Wydawnictwo Adam Marszałek, 2011.

Milyukov, Pavel N. Glavnyye techeniya russkoy istoricheskoy mysli. Sankt-Peterburg: Izd-vo M.V. Averianova, 1913.

Myakishev, Vladimir P. "I. I. Lappo - uchenyy s zhivym chuvstvom istoricheskoy deystvitelnosti." Vestnik VGU. Seriya Gumanitarnyye nauki 1 (2004): 162-176. Accessed July 1, 2019. http://kfinkelshteyn.narod.ru/Tzarskoye_Selo/Uch_zav/Nik_ Gimn/NG_prep_Lappo_Miakishev.htm

Polevoy, Nikolay A. Istoriya russkogo naroda, vol. 5. Moskva: Tipografiya Avgusta Semena, 1833.

Ragauskas, Aivas. "Istorikas I. Lappo ir Lietuva." In Lietuvos istorijos metraštis, 81-91. Vilnius: Mokslo ir enciklopeidjų leidyka, 1994.

Rusina, Jelena. "Unia lubelska w historiografii ukraińskiej." In Unia lubelska. Idea i jej kontynuacja. Materiały z międzynarodowej konferencji naukowej, która odbyła się w dniach 19-20 listopada 2009 roku w Wilnie w Muzeum Sztuki Użytkowej, edited by Liudas Glemža and Ramunė Šmigelskytė-Stukienė, 389-394. Vilnius: Nacionalinis muziejus Lietuvos Didziosios Kunigaikstystes valdovu rumai, 2011.

Shcherbatov, Mikhail M. Istoriya rossiyskaya ot drevneyshikh vremen. Sankt-Peterburg: Imperatorskaya Akademiya nauk, 1770-1791. 
Sheyfer, Valery. "Dzyarzhaŭnyya unii Vyalikaga Knyastva Litoŭskaga i Karaleŭstva Polskaga ŭ atsentsy raseyskay gistaryyagrafii 19 - pershykh dzesyatsigoddzyaŭ 20 st." Gistarychny Almanakh 5 (2000): 123-134.

Smirnov, Mikhail P. "Spor mezhdu Litvoy i Polshey o pravakh na Volyn i Podoliyu." In Torzhestvennyy akt Rishelyevskogo litseya po sluchayu okonchaniya 1862-63 akademicheskogo goda, 5-71. Odessa: Tipografiya Frantsova, 1863.

Smirnov, Mikhail P. "Yagello-Yakov-Vladislav i pervoye soyedineniye Litvy s Polshey." Zapiski Imperatorskogo Novorossiyskogo universiteta 2 (1868): 1-259.

Solovyev, Sergey M. "Ocherk istorii Malorossii do podchineniya eye tsaryu Alekseyu Mikhaylovichu." Otechestvennyye zapiski 11 (1848): 1-34.

Solovyev, Sergey M. Istoriya Rossii s drevneyshikh vremen, vol. 1-6. Sankt-Peterburg: Tovarishchestvo „Obshchestvennaya polza”, 1851-1879.

Stolyarov, Aleksey M. "Istoriya Velikogo knyazhestva Litovskogo v otechestvennoy istoriografii XIX - nachala XX veka." PhD diss., [Kazan State University], 2008.

Tsvikevich, Alyaksandr I. Zapadno-russizm. Narysy z gistoryi gramadskay mysli na Belarusi u XIX i pachatku XX v. Minsk: Navuka i tekhnika, 1993.

Ustryalov, Nikolay G. Issledovaniye voprosa, kakoye mesto v russkoy istorii dolzhno zanimat Velikoye knyazhestvo Litovskoye. Sankt-Peterburg: Tipografiya Ekspeditsii zagotovleniya gosudarstvennykh bumag, 1839.

Ustryalov, Nikolay G. Russkaya istoriya, vol. 1-5. Sankt-Peterburg: Tipografiya Ekspeditsii zagotovleniya gosudarstvennykh bumag, 1837-1841.

Zakrzewski, Andrzej B. Wielkie Księstwo Litewskie (XVI-XVIII w.). Prawo - ustrój społeczeństwo. Warszawa: Wydawnictwo „Campidoglio”, 2013.

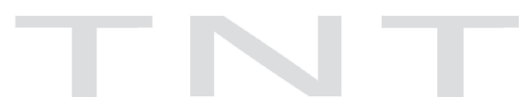

